\title{
Burnstock and the legacy of the inhibitory junction potential and P2Y1 receptors
}

\author{
Brian F. King ${ }^{1}$ \\ Received: 7 September 2020 / Accepted: 13 October 2020 / Published online: 30 October 2020 \\ (C) The Author(s) 2020
}

\begin{abstract}
The synaptic event called the inhibitory junction potential (IJP) was arguably one of the more important discoveries made by Burnstock and arguably one of his finer legacies. The discovery of the IJP fundamentally changed how electromechanical coupling was visualised in gastrointestinal smooth muscle. Its discovery also set in motion the search for novel inhibitory neurotransmitters in the enteric nervous system, eventually leading to proposal that ATP or a related nucleotide was a major inhibitory transmitter. The subsequent development of purinergic signalling gave impetus to expanding the classification of surface receptors for extracellular ATP, not only in the GI tract but beyond, and then led to successive phases of medicinal chemistry as the P2 receptor field developed. Ultimately, the discovery of the IJP led to the successful cloning of the first P2Y receptor (chick P2Y1) and expansion of mammalian ATP receptors into two classes: metabotropic P2Y receptors (encompassing P2Y1, P2Y2, P2Y4, P2Y6, P2Y11-14 receptors) and ionotropic P2X receptors (encompassing homomeric P2X1-P2X7 receptors). Here, the causal relationship between the IJP and P2Y1 is explored, setting out the milestones reached and achievements made by Burnstock and his colleagues.
\end{abstract}

Keywords IJP $\cdot$ P2Y receptor $\cdot$ Smooth muscle $\cdot$ Enteric nervous system

$\begin{array}{ll}\text { Abbreviations } & \\ \text { ENK } & \text { Enkephalin } \\ \text { GRP } & \text { Gastrin-releasing peptide } \\ \text { GPCR } & \text { G protein-coupled receptor } \\ \text { MRS2179 } & \begin{array}{l}\text { 2'-Deoxy-N }{ }^{6} \text {-methyladenosine } \\ \text { 3',5'-bisphosphate }\end{array} \\ \text { MRS2279 } & \begin{array}{l}\text { 2-Chloro } \\ \text { N }\end{array} \\ & \text {-methyl-(N)-methanocarba- } \\ \text { 2'-deoxyadenosine-3',5'-bisphosphate } \\ \text { MRS2500 } & \text { 2-iodo-N }{ }^{6} \text {-methyl-(N)- } \\ & \text { methanocarba-2'-deoxyadenosine- } \\ & \text { 3',5'-bisphosphate } \\ \text { NOS } & \text { Nitric oxide synthase } \\ \text { PACAP } & \text { Pituitary adenylate-cyclase activating peptide }\end{array}$

This article is part of the Topical Collection on A Tribute to Professor Geoff Burnstock.

Brian F. King

b.king@ucl.ac.uk

1 Research Department of Neuroscience, Pharmacology \& Physiology (NPP), University College London (UCL), Gower Street,

London WC1E 6BT, UK $\begin{array}{ll}\text { PIT } & \text { 2,2-Pyridylisatogen Tosylate } \\ \text { SK channels } & \begin{array}{l}\text { Small-conductance } \\ \mathrm{Ca}^{2+} \text {-activated } \mathrm{K}^{+} \text {-channels }\end{array} \\ \text { TTX } & \text { Tetrodotoxin } \\ \text { VIP } & \text { Vasoactive intestinal polypeptide }\end{array}$

\section{Introduction}

Geoffrey Burnstock (1929-2020) was widely acknowledged for his pioneering work on ATP receptors. He defined ATP receptors as $\mathrm{P} 2$ receptors, in deference to the already established class of adenosine receptors which he would call P1 receptors. Later, he and Charles Kennedy would broaden the $\mathrm{P} 2$ receptors to $\mathrm{P} 2 \mathrm{X}$ and $\mathrm{P} 2 \mathrm{Y}$ subtypes - an expanded classification based on the pharmacological profile for each subtype. Burnstock applied Paton's criteria for the identification of a neurotransmitter, to define purinergic signalling as the release of packaged ATP from synaptic vesicles in enteric nerve endings. Afterwards, Burnstock proposed that ATP is stored and released with other transmitter substances by the same nerve endings in all peripheral nerves. The restlessness of his mind led to the proposal of families of nucleotide-gated ion channels and nucleotide-activated GPCRs. In fulfilment of 
his expectations, members of the $\mathrm{P} 2$ receptor gene family were isolated and their encoded peptides characterised in a relatively short of period of time (1992-2001). Burnstock helped lead the effort to clone the first member of $\mathrm{P} 2$ receptor family: chick P2Y1 receptor. The pursuit of P2Y1 led to my scientific collaboration with Geoff, an alliance which produced 59 shared publications and lasted for a period of 25 years (1992-2017). We were united by a passion for the synaptic physiology of the peripheral nervous system. This commentary describes key steps in the discovery of the IJP and involvement of P2Y1.

\section{Gastrointestinal physiology}

Before the coming of purinergic signalling [1, 2], an energised and successful Geoffrey Burnstock had spent more than 15 years making a significant contribution to our understanding of gastrointestinal smooth muscle motility. This early body of work began in 1953 with his postgraduate $(\mathrm{PhD})$ research on the alimentary canal of the brown trout [3]; this gastrointestinal theme would continue for the remainder of his scientific career.

Burnstock contributed to the development of gastrointestinal physiology in 2 ways: through methodology and through discovery. In terms of methodology, Burnstock modified the Sucrose-Gap technique of Stämpfli and Straub [4, 5], to record the membrane potential and action potentials of the external longitudinal muscle layer of the gut, thereby shedding light on the electromechanical coupling of gastrointestinal smooth muscle. Burnstock and Straub were the first to do so, overcoming the problems of recording electrical events during the powerful and spontaneous movements of drug-stimulated longitudinal muscle of the small intestine in pike, frog, rabbit, rat, guinea-pig and cat, the rectum of trout, and guinea-pig taenia coli [6]. The Sucrose-Gap technique would be employed time and again to elucidate the electrogenic actions of a wide range of excitatory and inhibitory drugs on the gastrointestinal tract. Later, Burnstock and colleagues also made intracellular recordings from smooth muscle cells using sharp microelectrodes, to corroborate the electrical events recorded first by the Sucrose-Gap technique [7-9]. Such knowledge led to the rapid advancement of understanding the actions of transmitters, hormones and drugs on smooth muscle in a body of work contained in 84 papers, prior to his seminal paper (his 85th paper) on "ATP or a related nucleotide" as an inhibitory transmitter [1].

In terms of discovery, Burnstock's defining contribution arguably came from the discovery of the inhibitory junction potential (IJP), a nerve-mediated hyperpolarisation of the membrane potential which preceded the relaxation of the longitudinal muscle in guinea-pig taenia coli [7-10]. In the fullness of time, it would be shown that ATP or a related nucleotide was the mediator of the IJP and contributed to the non- adrenergic, non-cholinergic relaxation (NANC relaxation) of the taenia coli $[1,2]$. Burnstock applied the term NANC for TTX-sensitive nerve-mediated events that persisted when adrenergic and cholinergic responses were attenuated by the action of bretylium (or guanethidine) and atropine, respectively. The existence of NANC nerves had long been debated, mostly in the process of excitatory and inhibitory neurotransmission in the CNS [11-13]. There was even measured support for ATP as a transmitter from the foremost CNS neuroscientists, as best exemplified by Krnjević in 1974: "Although it may seem wasteful to use a high-energy compound like ATP as a neurotransmitter, several features would make it very suitable for such a function" [13].

The purinergic IJP in gastrointestinal smooth muscle cells showed a latency of 100 milliseconds and more from the point of stimulation of NANC inhibitory nerves to the onset of the hyperpolarisation of the membrane potential caused by the opening of potassium channels; this latency was too long to be explained by the slowest conduction velocity of unmyelinated C-fibre nerves in the GI tract [7-10]. Instead, this unexplained long latency presaged the involvement of a metabotropic receptor, with ATP first activating a surface receptor to produce an intracellular signalling molecule and cause the downstream opening of potassium channels. In the fullness of time, it would be shown that ATP acts through Gqcoupled $\mathrm{P} 2 \mathrm{Y} 1$ receptors, leading to $\mathrm{IP}_{3}$-mediated calcium release, opening of small-conductance, calcium-activated potassium channels (SK channels, which are blocked by the beesting venom apamin), a resultant outward potassium current $\left(I_{K(\mathrm{Ca})}\right)$ which hyperpolarises the membrane potential of smooth muscle cells and, in turn, closes voltage-gated calcium channels to reduce free calcium levels in the intracellular fluid of smooth muscle, and finally reduces the contractility of smooth muscle [reviewed in: 14-17]. The purinergic IJP, identified first in the taenia coli of the caecum, has been demonstrated in the smooth muscle layers of mammalian stomach, small intestine, and large intestine [14-17].

\section{Inhibitory junction potentials (IJPs)}

The purinergic IJP discovered by Burnstock is remarkable for both its brevity and large amplitude, in response to single electrical shocks applied to the intrinsic inhibitory nerves of the gut. The resultant IJP lasts only 500 to $1200 \mathrm{~ms}$, yet shows an amplitude of $20 \mathrm{mV}$ and more (Fig. 1a). When spontaneous mechanical activity of smooth muscle is abolished by nifedipine (L-type $\mathrm{Ca}^{2+}$-channel blocker), the duration of the purinergic IJP is slightly longer at around $1700 \mathrm{~ms}$ with a latency of onset of around $150 \mathrm{~ms}$, but the amplitude is no larger [18]. The time-to peak of the purinergic IJP is around $300 \mathrm{~ms}$ [19]. For gastrointestinal smooth muscle, the purinergic IJP represents the fastest of inhibitory events and now is routinely called the fast-JP (fIJP, f-IJP, or IJP-f). In 
a

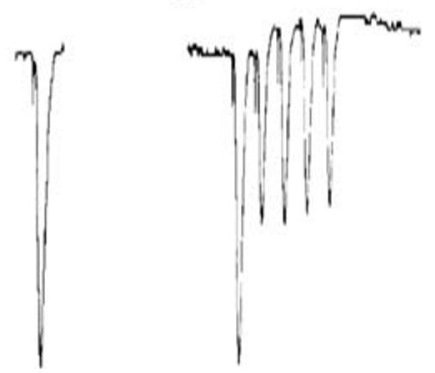

C

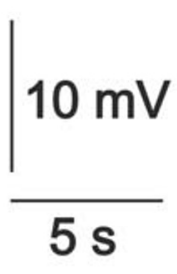

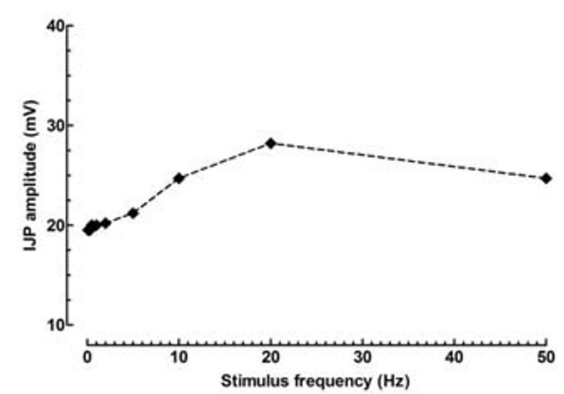

Fig. 1 The purinergic IJP (recorded by using an intracellular microelectrode) is a rapid hyperpolarisation of the membrane potential of a smooth muscle cells $\left(E_{m}=-56 \mathrm{mV}\right)$; in this case, in the circular layer of the muscularis extrema of the guinea-pig ileum. a The recorded electrical event is short in duration ( $1 \mathrm{~s})$ but large in amplitude $(20 \mathrm{mV})$ in response to single electrical shocks applied by field stimulation of the intrinsic inhibitory nerves. b Repetitive stimulation of the intrinsic inhibitory nerves ( $1 \mathrm{~Hz}, 5$ pulses) leads to rundown of the IJP-amplitude, a phenomenon associated with the availability of primed storage vesicles at

contrast, other inhibitory neurotransmitters identified later in the enteric nervous system evoke slower inhibitory events which are now routinely called the slow-IJP (sIJP, s-IJP, or IJP-s) [14-17].

The purinergic fast-IJP does not efficiently summate upon repetitive nerve stimulation and, instead, there is rundown in the amplitude of successive IJPs at stimulus frequencies higher than $0.1 \mathrm{~Hz}$ (1 pulse every $10 \mathrm{~s}$ ) (Fig. 1b). However, there is still limited summation at higher stimulus frequencies. The purinergic fast-IJP to single electric shocks is around 70\% of the maximum IJP-amplitude; a higher number of pulses or a higher frequency of pulses marginally enhances the amplitude of the resultant compound IJP (Fig. 1c). The maximal amplitude of the purinergic fast-IJP depends on the difference between the membrane potential of smooth muscle $\left(E_{m}\right)$ and the reversal potential for potassium channels $\left(E_{K}\right)$. Thus, the maximum amplitude of the fast-IJP is defined by the driving force $\left(E_{K}-E_{m}\right)$ and is around $25-30 \mathrm{mV}$ with $E_{m}$ values of $-60 \mathrm{mV}$ and $E_{K}$ of -85 to $-90 \mathrm{mV}$ (Fig. 1c). Since single electrical shocks so efficaciously produce a fast-IJP of $20 \mathrm{mV}$ in amplitude, the purinergic fast-IJP is both powerful and synaptically economical.

The purinergic fast-IJP is often accompanied by a nonpurinergic slow-IJP in many smooth muscle bands of the gut $[20,21]$. This is certainly true for guinea-pig taenia coli $[18$, 22], which Burnstock had used regularly in his studies of purinergic signalling. The nature of the slow-IJP is beyond the scope of this commentary but involves the production and release of nitric oxide (NO) from intrinsic inhibitory nerves, and activation of cGMP-dependent potassium channels in smooth muscle. Notably, the slow-IJP summates with increasing numbers of stimulus pulses or increasing stimulus frequency. Both ATP and NO are considered to be co-released by the intrinsic inhibitory nerves of the gut. There is co- the active zone of the nerve varicosities where transmitters are released. $\mathbf{c}$ IJPs do summate if the interval between successive IJPs is sufficiently brief $(100 \mathrm{~ms}$ at a stimulus frequency of $10 \mathrm{~Hz}, 5$ pulses $)$. The maximum amplitude of the compound IJP is approximately $30 \mathrm{mV}$ for intracellular recordings made from the circular muscle of the guinea-pig ileum (King: unpublished data). The maximum amplitude of hyperpolarisation evoked by extracellularly-applied ATP $(100 \mathrm{mM})$ is around $30 \mathrm{mV}$ in the same tissue [54]

localisation of ATP-containing storage vesicles and $\mathrm{nNOS} \alpha$ in nerve varicosities harvested from the myenteric plexus; their presence in synaptic varicosities is dependent on intraaxonal kinesin and myosin motors in intrinsic inhibitory nerves $[23,24]$. Accordingly, purinergic and nitrergic transmission in the gut are impaired in mice deficient in the transport motor, myosin Va [23, 24]. Neuronal nitric oxide synthase (nNOS) is now used as a marker in intrinsic inhibitory nerves for the co-localisation of ATP, NO and yet another peptidergic inhibitory transmitter responsible for a prolonged-IJP (which involves either PACAP or VIP) [15]. These intrinsic inhibitory nerves are classed phenotypically as ATP/NOS/VIP/PACAP/ENK (short anal projection) and ATP/NOS/VIP/PACAP/GRP (long anal projection) for descending inhibitory pathways to the circular muscle of the guinea-pig ileum [15]. It has been postulated that purinergic inhibition is concerned more with descending inhibition in the peristaltic reflex, whereas nitrergic inhibition may determine the general degree of excitability and contractility of smooth muscle [25]. To this end, there is a decreased rate in P2Y1 knockout mice of the colonic transit of faecal pellets which is also observed in WT-mice treated with the selective P2Y1 antagonist, MRS2500 [21]. On the other hand, the impairment of nitrergic transmission caused by polymorphisms of the NOS-1 gene is strongly associated with oesophageal muscle spasm (achalasia) in human infants [26].

\section{Metabotropic P2Y receptors}

Burnstock proposed the existence of extended families of metabotropic and ionotropic ATP receptors [27], based on the discovery of two cloned P2Y receptors now named P2Y1 and P2Y2 $[28,29]$ and two cloned P2X receptors now named $\mathrm{P} 2 \mathrm{X} 1$ and P2X2 [30, 31]. The numbering system developed 
by Burnstock for these extended families of cloned P2 receptors is summarised elsewhere, yet represents a fundamental element of housekeeping in the P2 receptor field [32]. The cloned P2Y receptor proteins are 328-377 amino acids in length and are some of the shorter GPCRs found in mammalian cells. They possess seven hydrophobic regions, forming the trans-membrane spanning regions TM1-TM7, which lie between an extracellular N-terminus (27-51 residues in length) and cytosolic C-terminus (15-68 residues in length), with consensus motifs for intracellular kinases on the intracellular loops and cytosolic C-terminus (Fig. 2). Alignment of the protein sequences for the TM1-TM7 region reveals $17-62 \%$ identity (35-80\% similarity) [33].

Burnstock helped lead the effort to clone ATP receptors. The first recombinant ATP receptor was chick P2Y1 (cP2Y1), isolated as clone 803 from a cDNA library of chick brain screened for homologous sequences to a partial guinea-pig adenosine-like sequence (RDC1) [28]. When the chick is close to hatching, its brain undergoes a rapid phase of expression of receptor mRNAs; accordingly, the hatched chick is a highly precocious neonate. Impressively high levels of P2Y1 receptor expression were observed for $\left[{ }^{35} \mathrm{~S}\right]-\mathrm{dATP} \alpha \mathrm{S}$ radioligand binding in chick brain $(37 \mathrm{pmol} / \mathrm{mg}$ protein for cP2Y1 versus $1-2 \mathrm{pmol} / \mathrm{mg}$ protein for muscimol binding at $\left.\mathrm{GABA}_{\mathrm{A}}\right)[28,34]$. Transcripts for chick P2Y1 are not only localised in neurons and astrocytes of the brain; its mRNA is present in spinal cord, gastrointestinal tract, spleen, and leg muscle in adult chicken [28]. A remarkably high level of $\mathrm{P} 2 \mathrm{Y} 1$ protein expression also was observed in neurons in the hippocampus of human brain [35], with a wide distribution of human P2Y1 (hP2Y1) in many other neuronal and nonneuronal peripheral tissues [36]. A full description of hP2Y1 expression and distribution appears online in the IUPHAR P2Y1 database [37].

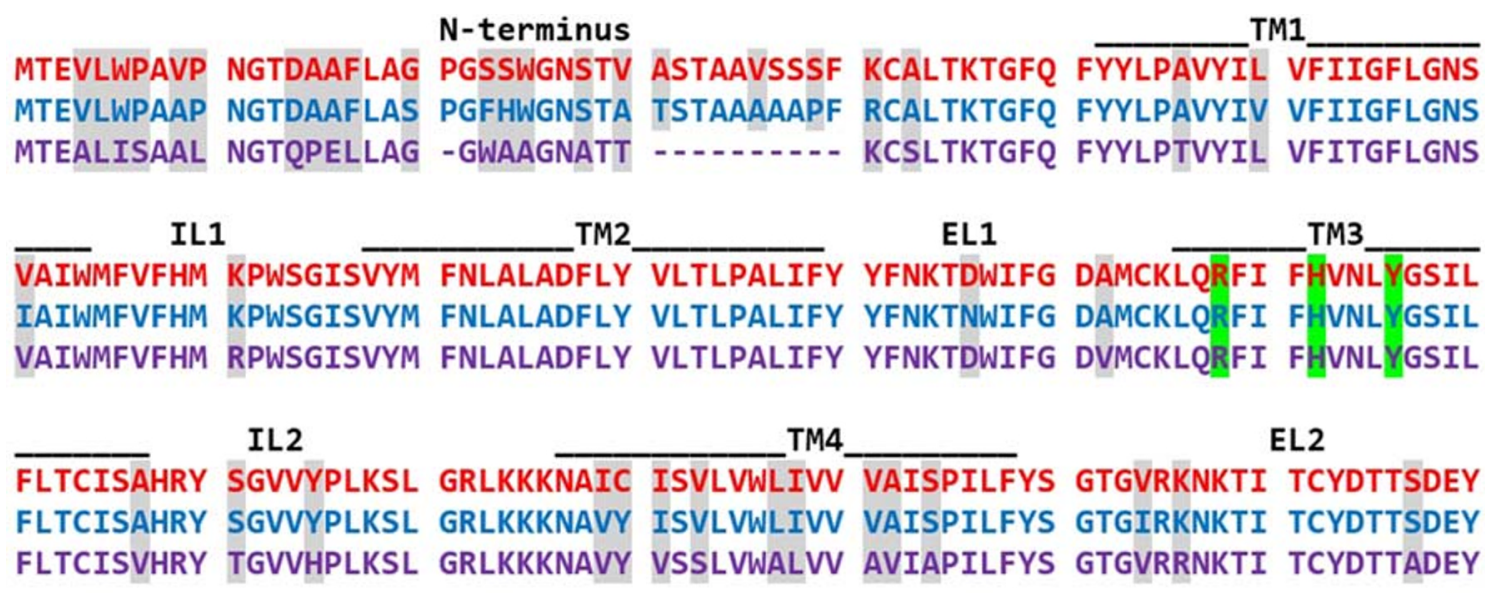

TM5

IL3

TM6

LRSYFIYSMC TTVAMFCVPL VLILGCYGLI VRALIYKDLD NSPLRRKSIY LVIIVLTVFA VSYIPFHVMK

LRSYFIYSMC TTVAMFCVPL VLILGCYGLI VRALIYKDLD NSPLRRKSIY LVIIVLTVFA VSYIPFHVMK LRSYFVYSMC TTVFMFCIPF IVILGCYGLI VKALIYKDLD NSPLRRKSIY LVIIVLTVFA VSYLPFHVMK

\begin{tabular}{|c|c|c|c|c|c|c|}
\hline \multicolumn{2}{|r|}{ EL3 } & \multicolumn{3}{|c|}{ TM7 } & \multicolumn{2}{|r|}{ c-terminus } \\
\hline TMNLRARLDF & QTPAMCAFND & RVYATYQVTR & $\overline{\text { GLASLNSCVD }}$ & $\overline{\text { PILYFLAGDT }}$ & FRRRLSRATR & KASRRSEANL \\
\hline TMNLRARLDF & QTPEMCTFND & RVYATYQVTR & GLASLNSCVD & PILYFLAGDT & FRRRLSRATR & KASRRSEANL \\
\hline TLNLRARLDF & QTPQMCAFND & KVYATYQVTR & GLASLNSCVD & PILYFLAGDT & FRRRLSRATR & KSSRRSEPNV \\
\hline
\end{tabular}

QSKSEDMTLN ILPEFKQNGD TSL (Human:373aa)
QSKSEDMTLN ILSEFKQNGD TSL (G-Pig:373aa)
QSKSEEMTLN ILTEYKQNGD TSL (Chick:362aa)

Fig. 2 The amino acid sequence of P2Y1 orthologues (human P2Y1, red; guinea-pig P2Y1, blue; chick P2Y1, purple). The location of the $\alpha$ helices forming the transmembrane spanning domains (TM1-TM7) are shown for the hP2Y1 crystal [40]. Extracellular loop (EL1-3) and intracellular loops (IL1-3) and N- and C-termini are shown too. P2Y sequences were aligned using Clustal Omega and anchored to the amino acid sequence for TM1 of hP2Y1. Human and guinea-pig P2Y1 peptides are 373 amino acids in length, whereas the $\mathrm{N}$-terminus of chick P2Y1 is shorter by 11 amino acids and the resultant peptide is 362 amino acids in length. Guinea-pig P2Y1 peptide is 95\% identical to human P2Y1, whereas chick P2Y1 is $83 \%$ identical to human P2Y1. Non-conserved amino acids are marked by grey shading. The amino acid residues marked by green shading are predicted to interact with the agonist 2-MeSADP by Molecular Dynamics modelling of the human P2Y1 crystal. These residues are conserved for the three P2Y1 orthologues and are predicted to form the binding pocket for 2-MeSADP [41] 
The pharmacological and operational profiles have been studied for chick P2Y1 expressed heterologously in Xenopus laevis oocytes, where agonist responses evoke a calciumdependent chloride current $\left(I_{\mathrm{Cl}(\mathrm{Ca})}\right)[28,38]$. ATP and not adenosine activated the chick ATP receptor, thus defining a P2 receptor (Fig. 3a). The reversal potential of ATP-evoked currents was around $-25 \mathrm{mV}$, implicating the involvement of a chloride current. Substitution of extracellular calcium ions with extracellular barium ions reduced the amplitude of $I_{\mathrm{Cl}(\mathrm{Ca})}$ evoked by either hyperpolarising voltage steps or extracellular ATP [28]. Chick P2Y1 showed an agonist potency order reminiscent of the mammalian native $\mathrm{P} 2 \mathrm{Y}$ receptor with 2MeSATP $>2$-MeSADP $>$ ATP $>$ ADP as agonists, while UTP, $\alpha, \beta$ meATP and BzATP were inactive (Fig. 3a,b). When the chick P2 receptor was expressed transiently in COS-7 cells, ATP receptor activation led to a suramin-sensitive increase in levels of intracellular inositol triphosphate $\left(\mathrm{IP}_{3}\right)$ [38]. The binding of the radioligand $\left[{ }^{35} \mathrm{~S}\right]-\mathrm{dATP} \alpha \mathrm{S}$ was displaced by 2-MeSATP $>$ ATP $>$ ADP at high affinity, whereas adenosine, $\beta, \gamma$ meATP and UTP did not [38]. The non-selective P2 receptors antagonists, suramin and Reactive Blue-2, reversibly antagonised evoked ATP-responses as either $I_{\mathrm{Cl}(\mathrm{Ca})}$ or raised $\mathrm{IP}_{3}$ levels at chick P2Y1 [38]. Thus, pharmacological, biochemical and structural data defined the chick P2Y1 receptor as the first metabotropic P2Y receptor. Over 280 species orthologues of $\mathrm{cP} 2 \mathrm{Y} 1$ have been cloned, including human P2Y1 where ADP and 2-MesADP are more potent agonists than ATP and 2-MeSATP [39]. The predicted binding site for 2-MeSADP has been elucidated by molecular dynamics modelling of the known human P2Y1 crystal [40, 41].

\section{Purinergic IJP and P2Y1receptors}

Based on the pharmacological profiling of native P2Y receptors [42], Burnstock proposed that $\mathrm{cP} 2 \mathrm{Y} 1$ was pharmacologically related to the ATP-activated $\mathrm{P} 2 \mathrm{Y}$ receptor in guinea-pig taenia coli [43]. Moreover, pyridylisatogen tosylate (PIT) was found to be a nonsurmountable antagonist at cP2Y1 (Fig. 3c) [44], with PIT also known to block ATP relaxations but not adenosine relaxations in the guinea-pig taenia coli [45]. Later, PIT would be shown to be a selective antagonist for human $\mathrm{P} 2 \mathrm{Y} 1$ receptors and not human P2Y2, P2Y4, P2Y6, P2Y11 or P2Y12 [46]. The guinea-pig P2Y1 (gpP2Y1) receptor has since been cloned and characterised by Wood and colleagues, with an agonist potency order of 2-MeSADP $>2$ MeSATP $>$ ADP $>$ ATP for gpP2Y1-evoked calcium signals in HEK293 cells [47]. PIT was not tested on gpP2Y1, but the P2Y1-selective antagonist MRS2179 was highly effective at blocking this recombinant $\mathrm{P} 2 \mathrm{Y}$ receptor [47].

The link between P2Y1 and the purinergic fast-IJP was better forged after the development by Jacobson of the deoxyadenosine bisphosphate derivatives (including MRS2179, MRS2279 and MRS2500) as highly-selective P2Y1 antagonists [48-50]. Burnstock did not play a major role in screening bisphosphate compounds as $\mathrm{P} 2 \mathrm{Y} 1$ receptor antagonists; instead, our laboratory carried out complementary tests on these bisphosphates for activity at recombinant $\mathrm{P} 2 \mathrm{X}$ receptors [51]. The blocking activity of commercially available MRS2179 was first confirmed for the fast-IJP of the circular and longitudinal muscle layers of the human colon [52]. Later, the blocking activity of MRS2279 and MRS2500 was confirmed for the purinergic fast-IJP of the circular muscle layer of the human colon [53]. Ultimately, the involvement of P2Y1 in the purinergic fast-IJP was solidified using P2Y1null mice and by cross-comparison of knockout data from WT-mice treated with selective P2Y1 antagonists [20, 21].

\section{Summary}

The early discovery of the IJP by Burnstock was a potent stimulus for wide ranging research over many successive decades. It caused us to reflect on how neurotransmitters operate potassium channels and which neurotransmitters other than
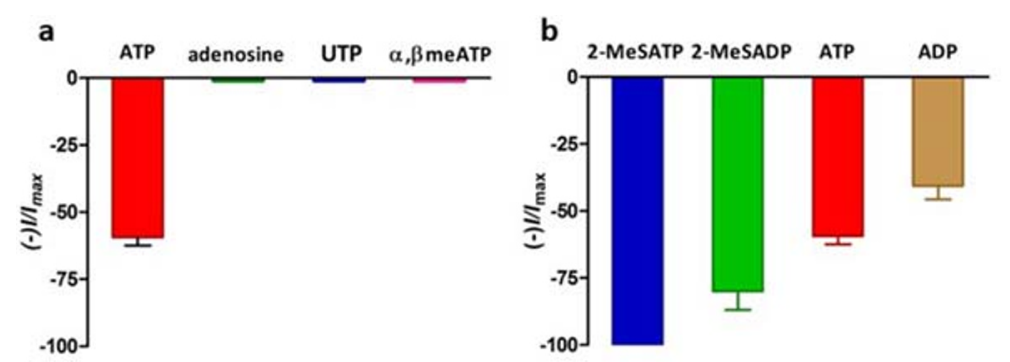

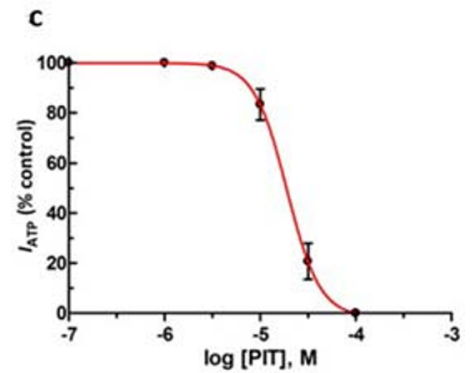

Fig. 3 Pharmacological profile of $\mathrm{cP} 2 \mathrm{Y} 1$ expressed in Xenopus laevis oocytes. a Chick ATP receptor was defined as a P2 receptor and not a $\mathrm{P} 1$ receptor, because it was activated by ATP but not by adenosine. The activity of ATP but not UTP and $\alpha, \beta$ meATP defined a P2Y receptor and excluded the involvement of P2U or P2X receptors. b Chick ATP receptor was activated potently by 2-MesATP and 2-MeSADP which were full agonists, whereas ATP and ADP were partial agonists. $\mathrm{EC}_{50}$ values were: 2 -MeSATP, $10 \pm 1 \mathrm{nM}$; ATP, $155 \pm 50 \mathrm{nM}$; ADP, $258 \pm$ $40 \mathrm{nM}$. Nucleotide responses were inward chloride currents $\left(V_{h},-\right.$ $40 \mathrm{mV}$ ) and all agonists were tested at $1 \mu \mathrm{M}$ for $60 \mathrm{~s}$, every $30 \mathrm{~min}$. c ATP responses at the chick $\mathrm{P} 2 \mathrm{Y}$ receptor were antagonised in a nonsurmountable way by 2,2-Pyridylisatogen Tosylate (PIT, $0.1-$ $100 \mu \mathrm{M})$, with an $\mathrm{IC}_{50}$ value of $13.2 \pm 9 \mu \mathrm{M}$ [44]. PIT blocks ATP responses, but not adenosine responses, in the guinea-pig taenia coli [45] 
acetylcholine and noradrenaline could do so in the peripheral nervous system. It led to the proposal that ATP itself is a transmitter. In turn, it caused us to study receptor mechanisms and explore the attendant medicinal chemistry of ATP receptors. It led to studies on the molecular signalling of ATP receptors and structure of ATP receptors. Cloning of chick P2Y1 led to homology screening and discovery of a broad family of P2Y receptors, the distribution of which led to wider research on the fundaments of cell physiology and experimental medicine. It gave rise to further medicinal chemistry for P2Y subtype-selective agonists and antagonists as potential therapeutics for human diseases. This enduring legacy has served science well for almost 6 decades; it will be interesting to see how farther the Burnstock legacy will take us.

\section{Compliance with ethical standards}

Conflict of interest The author declares that he has no conflict of interest.

Ethical approval Whereas data in this paper were obtained from animal studies in orginial studies, no animals were used for the purpose of this review article.

Open Access This article is licensed under a Creative Commons Attribution 4.0 International License, which permits use, sharing, adaptation, distribution and reproduction in any medium or format, as long as you give appropriate credit to the original author(s) and the source, provide a link to the Creative Commons licence, and indicate if changes were made. The images or other third party material in this article are included in the article's Creative Commons licence, unless indicated otherwise in a credit line to the material. If material is not included in the article's Creative Commons licence and your intended use is not permitted by statutory regulation or exceeds the permitted use, you will need to obtain permission directly from the copyright holder. To view a copy of this licence, visit http://creativecommons.org/licenses/by/4.0/.

\section{References}

1. Burnstock G, Campbell G, Satchell D, Smythe A (1970) Evidence that adenosine triphosphate or a related nucleotide is the transmitter substance released by non-adrenergic inhibitory nerves in the gut. Brit J Pharmacol 40:668-688

2. Burnstock G (1972) Purinergic nerves. Pharmacol Rev 24:509-581

3. Burnstock G (1957) The musculature, innervation and motility of the alimentary canal of the brown trout. Thesis $(\mathrm{PhD})$ - University of London (King's college)

4. Stämpfli R (1953) A new method for measuring membrane potentials with external electrodes. Experientia 10:508-509

5. Stämpfli R, Straub RW (1955) Changes of the membrane potential of myelinized nerve fibres produced by different chemical and pharmacological agents. J Physiol Paris 47:314

6. Burnstock G, Straub RW (1958) A method for studying the effects of ions and drugs on the resting and action potentials in smooth muscle with external electrodes. J Physiol 140:156-167

7. Burnstock G, Campbell G, Bennett M, Holman ME (1963) Inhibition of the smooth muscle of the taenia coli. Nature 200: $581-582$
8. Bennett M, Burnstock G (1966) Application of the sucrose-gap method to determine the ionic basis of the membrane potential of smooth muscle. J Physiol 183:637-648

9. Burnstock G, Campbell G, Rand MJ (1966) The inhibitory innervation of the taenia of the guinea-pig caecum. J Physiol 182:504526

10. Tomita $\mathrm{T}$ (1972) Conductance change during the inhibitory potential in the guinea-pig taenia coli. J Physiol 225:693-703

11. Paton WDM (1958) Central and synaptic transmission in the nervous system (pharmacological aspects). Annu Rev Physiol 20:431470

12. Crossland $\mathbf{J}$ (1960) Chemical transmission in the central nervous system. J Pharm Pharmacol 12:1-36

13. Krnjević K (1974) Chemical nature of synaptic transmission in vertebrates. Physiol Rev 54:418-540

14. Kuriyama H, Kitamura K, Itoh T, Inoue R (1998) Physiological features of visceral smooth muscle cells, with special reference to receptors and ion channels. Physiol Rev 78:811-920

15. Bornstein JC (2008) Purinergic mechanisms in the control of gastrointestinal motility. Purinergic Signal 4:197-212

16. King BF (2015) Purinergic signalling in the enteric nervous system: (an overview of current perspectives). Auton Neurosci 191:141147

17. Matsuda NM, Miller SM (2010) Non-adrenergic non-cholinergic inhibition of gastrointestinal smooth muscle and its intracellular mechanism(s). Fundam Clin Pharmacol 24:261-268

18. Bridgewater M, Cunnane TC, Brading AF (1995) Characteristic features of inhibitory junction potentials evoked by single stimuli in the guinea-pig isolated taenia caeci. J Physiol 485:145-155

19. Bülbring E, Tomita T (1967) Properties of the inhibitory potential of smooth muscle as observed in the response to field stimulation of the guinea-pig taenia coli. J Physiol 189:299-315

20. Hwang SJ, Blair PJ, Durnin L, Mutafova-Yambolieva V, Sanders KM, Ward SM (2012) P2Y1 purinoreceptors are fundamental to inhibitory motor control of murine colonic excitability and transit. J Physiol 590:1957-1972

21. Gallego D, Gil V, Martínez-Cutillas M, Mañé N, Martín MT, Jiménez M (2012) Purinergic neuromuscular transmission is absent in the colon of P2Y1 knocked out mice. J Physiol 590:1943-1956

22. Shuttleworth CW, Murphy R, Furness JB (1991) Evidence that nitric oxide participates in non-adrenergic inhibitory transmission to intestinal muscle in the guinea-pig. Neurosci Lett 130:77-80

23. Chaudhury A, He XD, Goyal RK (2011) Myosin Va plays a key role in nitrergic neurotransmission by transporting $\mathrm{nNOS} \alpha$ to enteric varicosity membrane. Am J Physiol Gastrointest Liver Physiol 301:G498-G507

24. Chaudhury A, He XD, Goyal RK (2012) Role of myosin Va in purinergic vesicular neurotransmission in the gut. Am J Physiol Gastrointest Liver Physiol 302:G598-G607

25. Gallego D, Mañé N, Gil V, Martínez-Cutillas M, Jiménez M (2016) Mechanisms responsible for neuromuscular relaxation in the gastrointestinal tract. Rev Esp Enferm Dig 108:721-731

26. Shteyer E, Edvardson S, Wynia-Smith SL, Pierri CL, Zangen T, Hashavya S, Begin M, Yaacov B, Cinamon Y, Koplewitz BZ, Vromen A, Elpeleg O, Smith BC (2015) Truncating mutation in the nitric oxide synthase 1 gene is associated with infantile achalasia. Gastroenterology 148:533-536

27. Abbracchio MP, Burnstock G (1994) Purinoceptors: are there families of P2X and P2Y purinoceptors? Pharmacol Ther 64:445-475

28. Webb TE, Simon J, Krishek BJ, Bateson AN, Smart TG, King BF, Burnstock G, Barnard EA (1993) Cloning and functional expression of a brain G-protein-coupled ATP receptor. FEBS Lett 324: 219-225

29. Lustig KD, Shiau AK, Brake AJ, Julius D (1993) Expression cloning of an ATP receptor from mouse neuroblastoma cells. Proc Natl Acad Sci U S A 90:5113-5117 
30. Valera S, Hussy N, Evans RJ, Adami N, North RA, Surprenant A, Buell G (1994) A new class of ligand-gated ion channel defined by P2X receptor for extracellular ATP. Nature 371:516-519

31. Brake AJ, Wagenbach MJ, Julius D (1994) New structural motif for ligand-gated ion channels defined by an ionotropic ATP receptor. Nature 371:519-523

32. Burnstock G, King BF (1996) The numbering of cloned P2 purinoceptors. Drug Dev Res 38:67-71

33. King BF, Burnstock G (2002) Purinergic receptors. In: Pangalos MN, Davies CH (eds.) Understanding G proteincoupled receptors and their role in the CNS. Oxford University Press, Oxford, Ch21, pp 422-438

34. Webb TE, Simon J, Barnard EA (1998) Regional distribution of $\left[{ }^{35} \mathrm{~S}\right] 2$ '-deoxy 5'-O-(1-thio) ATP binding sites and the P2Y1 messenger RNA within the chick brain. Neuroscience 84:825-837

35. Moore D, Chambers J, Waldvogel H, Faull R, Emson P (2000) Regional and cellular distribution of the $\mathrm{P} 2 \mathrm{Y} 1$ purinergic receptor in the human brain: striking neuronal localisation. J Comp Neurol 421:3743-3784

36. Moore DJ, Chambers JK, Wahlin JP, Tan KB, Moore GB, Jenkins O, Emson PC, Murdock PR (2001) Expression pattern of human P2Y receptor subtypes: a quantitative reverse transcriptionpolymerase chain reaction study. Biochim Biophys Acta 1521: 107-119

37. IUPHAR (n.d.) P2Y1 database: https://doi.org/10.2218/gtopdb/F52/ 2019.4

38. Simon J, Webb TE, King BF, Burnstock G, Barnard EA (1995) Characterisation of a recombinant $\mathrm{P} 2 \mathrm{Y}$ purinoceptor. Eur $\mathrm{J}$ Pharmacol 291:281-289

39. Schachter JB, Li Q, Boyer JL, Nicholas RA, Harden TK (1996) Second messenger cascade specificity and pharmacological selectivity of the human P2Y1-purinoceptor. Br J Pharmacol 118:167-173

40. Zhang D, Gao ZG, Zhang K, Kiselev E, Crane S, Wang J, Paoletta S, Yi C, Ma L, Zhang W, Han GW, Liu H, Cherezov V, Katritch V, Jiang H, Stevens RC, Jacobson KA, Zhao Q, Wu B (2015) Two disparate ligand-binding sites in the human P2Y1 receptor. Nature 520:317-321

41. Li Y, Yin C, Liu P, Li D, Lin J (2017) Identification of a different agonist-binding site and activation mechanism of the human P2Y1 receptor. Sci Rep 7:13764

42. Burnstock G, Kennedy C (1985) Is there a basis for distinguishing two types of P2-purinoceptor? Gen Pharmacol 16:433-440

43. King BF, Townsend-Nicholson A, Burnstock G (1998) Metabotropic receptors for ATP and UTP: exploring the correspondence between native and recombinant nucleotide receptors. Trends Pharmacol Sci 19:506-514

44. King BF, Dacquet C, Ziganshin AU, Weetman DF, Burnstock G, Vanhoutte PM, Spedding M (1996) Potentiation by 2,2'pyridylisatogen tosylate of ATP-responses at a recombinant P2Y1 purinoceptor. Brit J Pharmacol 117:1111-1118

45. Spedding M, Weetman DF (1976) Identification of separate receptors for adenosine and adenosine 5 '-triphosphate in causing relaxations of the isolated taenia of the guinea-pig caecum. Br J Pharmacol 57:305-310

46. Gao ZG, Mamedova L, Tchilibon S, Gross AS, Jacobson KA (2004) 2,2'-Pyridylisatogen tosylate antagonizes P2Y1 receptor signalling without affecting nucleotide binding. Biochem Pharmacol 68:231-237
47. Gao N, Hu HZ, Zhu MX, Fang X, Liu S, Gao C, Wood JD (2006) The P2Y purinergic receptor expressed by enteric neurones in guinea-pig intestine. Neurogastroenterol Motil 18:316-323

48. Camaioni E, Boyer JL, Mohanram A, Harden TK, Jacobson KA (1998) Deoxyadenosine bisphosphate derivatives as potent antagonists at P2Y1 receptors. J Med Chem 41:183-190

49. Nandanan E, Jang SY, Moro S, Kim HO, Siddiqui MA, Russ P, Marquez VE, Busson R, Herdewijn P, Harden TK, Boyer JL, Jacobson KA (2000) Synthesis, biological activity, and molecular modeling of ribose-modified deoxyadenosine bisphosphate analogues as P2Y1 receptor ligands. J Med Chem 43:829-842

50. Kim HS, Ohno M, Xu B, Kim HO, Choi Y, Ji XD, Maddileti S, Marquez VE, Harden TK, Jacobson KA (2003) 2-substitution of adenine nucleotide analogues containing a bicyclo[3.1.0]hexane ring system locked in a northern conformation: enhanced potency as P2Y1 receptor antagonists. J Med Chem 46:4974-4987

51. Jacobson KA, Hoffmann C, Kim YC, Camaioni E, Nandanan E, Jang SY, Guo DP, Ji XD, von Kügelgen I, Moro S, Ziganshin AU, Rychkov A, King BF, Brown SG, Wildman SS, Burnstock G, Boyer JL, Mohanram A, Harden TK (1999) Molecular recognition in P2 receptors: ligand development aided by molecular modeling and mutagenesis. Prog Brain Res 120:119-132

52. Gallego D, Hernández P, Clavé P, Jiménez M (2006) P2Y1 receptors mediate inhibitory purinergic neuromuscular transmission in the human colon. Am J Physiol Gastrointest Liver Physiol 291: G584-G594

53. Gallego D, Gil V, Aleu J, Martinez-Cutillas M, Clavé P, Jimenez MM (2011) Pharmacological characterization of purinergic inhibitory neuromuscular transmission in the human colon. Neurogastroenterol Motil 23:792-e338

54. Wang GD, Wang XY, Hu HZ, Liu S, Gao N, Fang X, Xia Y, Wood JD (2007) Inhibitory neuromuscular transmission mediated by the P2Y1 purinergic receptor in Guinea pig small intestine. Am J Physiol Gastrointest Liver Physiol 292:G1483-G1489

Publisher's note Springer Nature remains neutral with regard to jurisdictional claims in published maps and institutional affiliations.

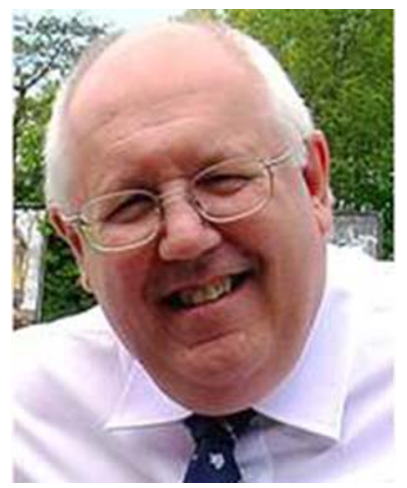

Brian King specialises in gastrointestinal physiology, particularly autonomic neuroscience and smooth muscle motility. My research began with the discovery of NANC inhibitory pelvic nerves which evoked slow IJPs in the rectococcygeus muscle in 1977. In collaboration with Geoffrey Burnstock, my research continued with studies of the purinergic fast IJP. Together, we characterised the recombinant chick $\mathrm{P} 2 \mathrm{Y} 1$ in 1992. 